日消外会誌 $12(2): 99 \sim 108,1979$ 年

\title{
早期胃癌診断の実態と評価
}

\begin{tabular}{lccccc}
\multicolumn{5}{c}{ 東京女子医科大学消化器病センター外科 } \\
鈴木 & 茂 & 村上 & 平 & 橋本 & 忠美 \\
長谷川利弘 & 川田 & 彰得 & 山田 & 明義 \\
鈴木 博孝 & 榊原 & 宣 & 遠藤 & 光夫 \\
小林誠一郎 & & & &
\end{tabular}

\section{PRESENT STATUS AND EVALUATION OF CLINICAL DIAGNOSIS FOR EARLY GASTRIC CANCER}

\begin{abstract}
Shigeru SUZUKI, M.D., Hitoshi MURAKAMI, M.D., Tadayoshi HASHIMOTO, M.D., Toshihiro HASEGAWA, M.D., Akinori KAWADA, M.D., Akiyoshi YAMADA, M.D., Hiroyoshi SUZUKI, M.D., Noburu SAKAKIBARA, M.D., Mitsuo ENDO, M.D. and Seiichiro KOBAYASHI, M.D.
\end{abstract}

Institute of Gastroenterology, Tokyo Women's Medical College, Tokyo

胃癌の予後が悪いことは周知のことであるが，これを早期胃癌の段階で治療すればその五生率は $90 \%$ 以 上である. そこで早期胃癌688病巣を細かく分析し，上り多くの早期胃癌発見のためには現在何が必要であ るかを探ってみた．X線，内視鏡の併用はもちろんであるがまず内視鏡器種は1本にこだわらずそれぞれ の欠点を補うような組合せで使用乙，胃体上部から噴門部の病変を見落さ妨とと，生検は胃体部からとく に慎重に行らこと，Il b の発見には色調の变化を重視し，確実な生検を行うこと，正型の診断には潰湟全周 からの的確な生検が必要であること, 微小癌はわずかな変化の発見と第 1 個目の生検組織採取を確実に行 らこと,などが重要であることが判明した。これにさらに最近の色素法等の補助診断の活用む望まれる.

索引用語：早期男癌．胃癌の靖断

はじめに

近年, 癌腫に対する化学療法, 免疫療法の研究が進 み、これにともない癌治療への関心も，むしろこの方面 に向けられ診断学そのるのはあまり顧みられない傾向に さ劣る。しかし現実には胃癌の治療も早期発見から外 科治療に至るこの伝統的な手段に匹敵するような効果は これらの化学療法や免疫療法には残念ながらまだまだ期 待できない：このような事実を目の当りにするとき，臨 床医が自らの手でできる最も有効な癌の治療法何であ るかを再認識して欲しい気がするのである。

早期胃癌の遠隔成績を 5 年生存率でみると, 現在どこ の施設でもほぼ $90 \%$ 前後の好成績をあげている.このこ とは胃癌であってもそれを早期癌の段階で発見し，外科
治療が行われるならば, 大多数の患者はこの病気から救 われることを意味するのである.

そこで早期胃癌診断の現状を紹介し，上り多くの早期 胃癌発見のために，これまでの診断学に反省を加觉ると 同時に今後の展望も考察してみたい。

\section{1. 早期筲癌の頻度}

胃癌の消化器悪性腫瑒中に占める頻度が最も高いこと は周知の事実である.しかしこれもここ数年の間にわず かづつではあるが, 死亡数が減少の傾向にあるといわれ る .これは恐らく積極的な早期胃癌の発見と治療, 化 学療法剤の発達などに負らところが多いのであるう.と くに早期発見と外科治療はこの中でも最も効果をあげて いるように思われるのである.さてこの胃癌死亡率をさ 
表 1 全胃癌中に占める早期胃癌の頻度

\begin{tabular}{|c|c|c|}
\hline 進 行度 & 在例 数 & $\%$ \\
\hline 草期青密 & 601 & 16.4 \\
\hline 進行罪蒘 & 3062 & 83.6 \\
\hline at & 3663 & 100.0 \\
\hline
\end{tabular}

表 2 早期胃癌症例

(601症例，688病巣，1965-1975年)

\begin{tabular}{|c|c|c|}
\hline 型別分類 & 病 单 数 & 頻度 $(\%)$ \\
\hline $\begin{array}{c}\mathrm{I} \\
\mathrm{I}+\mathrm{II} \mathrm{a}\end{array}$ & $\begin{array}{r}66 \\
1\end{array}$ & 9.7 \\
\hline $\begin{array}{l}\quad \text { II } \\
\text { II } a+I I c \\
I I a+I\end{array}$ & $\begin{array}{r}91 \\
63 \\
2\end{array}$ & 22.7 \\
\hline $\begin{array}{c}\text { II b } \\
\text { II b + II } c\end{array}$ & $\begin{array}{r}32 \\
2\end{array}$ & 4.9 \\
\hline $\begin{array}{l}\quad \text { II } c \\
\text { II } c+\text { II a } \\
\text { II } c+\text { II b } \\
\text { II } c+\text { III }\end{array}$ & $\begin{array}{r}244 \\
58 \\
2 \\
83\end{array}$ & 56.3 \\
\hline $\begin{array}{c}\text { III } \\
\text { III + II c }\end{array}$ & $\begin{array}{l}12 \\
29\end{array}$ & 6.0 \\
\hline その他 & 3 & 0.4 \\
\hline it & 688 & 100.0 \\
\hline
\end{tabular}

らに減少させるためには早期癌の発見率の増加が何にも 増して重要であることは論をまたない。

実際に全胃癌例中に占める早期胃癌の割合は著者らの 施設では表 1 の゙とくわずか $16.4 \%$ であ.他の施設で るほぼ同様の傾向を示している．胃癌の死亡率を減少さ せるためには，まずこの早期癌の割合を増加させること が第一でなければならない，恐らくこれが50\%以上にな った時, 死亡率は飛躍的に減少するであろらと思われる のである.このためには 1 例でも多くの早期癌を発見す ることであるが，これにはより多くの臨床医の努力が必 要であると同時に, 全国的な規模でのより一層の癌㤵蒙 が望まれるのである。

次に参考までに診断された早期胃癌の肉眼形態を早期 胃癌分類に沿って分けてみると表 2 のようになる。やは り II c を中心とする宿凹型が多く，II b や吕はきわめて 少ないことが目立っている.これは今後の早期胃癌診断 の焦点がいかなる所にあるかをよく物語っているといえ 上万.

\section{2. 早期罢癌の遠隔成悢}

図 1 胃癌の遠隔成績

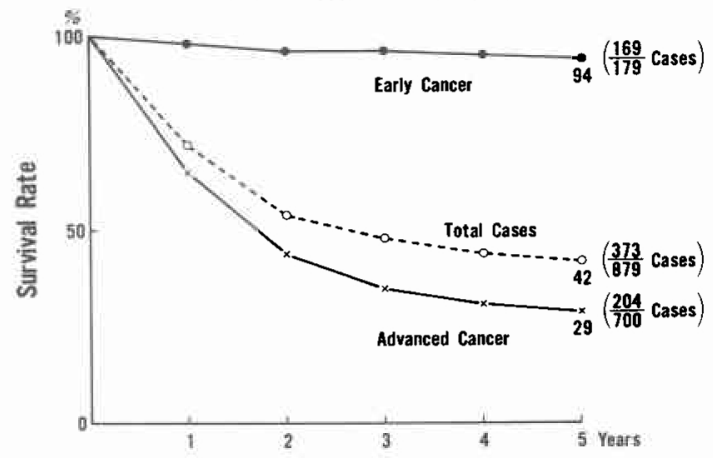

現状では胃癌の遠隔成績も他臓器の悪性腫瘍のそれと 同様に必ずしも良好であるとはいえない，とくに進行胃 癌の予後の不良なことは一般によく知られている。一 方, 早期胃癌となると逆にその遠隔はさわめて良好であ るといえる。

図 1 は著者らの施設での 5 年遠隔を各年毎の単なる生 存率から表示したものであるが，5年生存率が94\%とい ら良好な成績を示している。他の施設での報告をみて も, ほぼこれに近い生存率が示されている。例えば，林 田 $^{2)}$ の全国集計による5生率は98.6\%(他病死を除いた 5 生率), 北岡ら $3993.4 \%$ といら数値をあげている. 最 近の本田 ${ }^{4}$ の集計によれば早期胃癌の他病死も含めた 10 年生存率は $80.2 \%$ と報告されている.つまり早期胃癌の 長期遠隔は 5 年で $90 \%$ 以上という誠に良好な成績を兄て いることが理解でさよう。

胃以外の他の消化管癌での早期癌の遠隔成績は, 従来 胃癌活どに早期癌という観点での集計がなされていない ために，比較することはむずかしいが，最近それであよ うやく食道や大腸に拈いても症例数の增加がみられ，遠 隔成績它散見されるようになってきている．ところがこ れらの成績をみると必ずしも早期癌の 5 生率が早期胃癌 と同様によいとは限らないようである。たと流早期 食道癌 (表在癌) の5生率は約70\%と報告されている が5) $^{(5)}$ これは早期胃癌のそれに比べると大変悪い結果 となる。この相違の原因には多くの要因があるらが，早 期胃癌の遠隔が他蔵器の早期癌と比較してみても大変良 好なことが強調される点で, これからも胃癌の早期発 見, 早期治療の必要性が痛感されるわけである。

\section{3. 早期胃䖒診断の現況}

X線学的にも内視鏡学的にも最近, 早期癌診断に際立 った進展はみられていない，とくにX線的には、この傾 
向が強いように思う。これは早期胃癌の診断が力法論的 にすでK完成されたものと考光るべきなのか，1つの壁 に当っているのか，さらにはこれ対する一般の興味が 薄れたのか，いずれかが原因であるう．見方によれば， いずれの要素も含まれているのかむ知れない。

内視鏡診断の分野もむしろ後者の理由，つまり壁に当 り四苦入苦という状況がつづいているように見受けら れるが，これる内視鏡診断学の主流がむしろ他の方向 (ERCP とか Colonoscopy) 飞片寄り, 多くの有能な若 い新鮮な目がこれらに向さすぎているためであるかも知 れないわが国に批る胃癌死亡の頻度を考兄る時, も 5少しこの点は考慮されるべきであるらと思ら．単なる 流行現象であればよいがと念じずにはいられない。

それでも内視鏡の分野では比較的新しい技術の導入が この数年の間にみられている.したがってここでは次 に主として早期胃癌の内視鏡骖断の現況を中心に述べて みる。

1) 内視鏡器種の改良

早期胃癌の診断が胃カメラの普及によって著しく発展 したことは周知の事実であるが，この武器も現状ではも らすでに古く，胃カメラや初期のファイバースコープは 使用していないといら施設の方が多くなっている。そし て現在胃内視鏡器種は大きく 4 種に分れるように思う. その 1 つは従来の胃カメラの伝統をつぐファイバース コープ付き胃カメラであろう。このようなるのとして GTF-S が出迴っている.

次は純粋にファイバースコープのみによるもので, こ れには 3 種があり，直視式（前方視式）のものと，側視 式のもの，そしてこの両者の中間ともい方る前方斜視 (GIF-K) や視野方向が直視・側視変換式のものの 3 種 である.

現在市販されているこれらの内視鏡器種はいずれも優 れた性能を持ち, 甲乙つけがたいるのであり, 慣れた器 種であればどれを用いてもよいと考えているが，各スコ ープにもそれぞれ特徴があるので，これをよくわきまえ てその長所を生かすことが重要である。ただ欲をいえ ば，その施設の性格や患者数等を加味して器種を選択す ることが望まれる。つまり集団検診的要素が強い施設で は GTF を主体とするもの，時間をかけて詳細な観察も 行劣場所では純ファイバースコープ,ないし GTF との併用といった選択もできる. Panendoscope といわ れるタイプのもの，例えば GIF，PFS 等の直視式のス コープは大変便利で, 上部消化管出血の際の緊急内視鏡
検查には久かせないものであるが，胃のみに限って，早 期癌の診断といらことになると，拡大観察は別としてや はりまだ側視式のものの方が優れているといわざるを党れ ない。これは主として直視式のものが胃癌の好発部位で ある胃体部小弯から幽門洞小弯にかけての観察にやや難 点があることによる.しかし最近ではこの直視式のもの もアングル機構が大幅に改善され盲点が少なくなりつつ あり，GIF-P2 のように細径である上に強アングルがき くものや PFS-B1200 II のような視野方向変換式の最新 型といった優れた器種も出てきているので, いずれ 1本 のファイバースュープですべての欲求を満足させるもの も出てこょう．ただ現状では早期胃癌に対する内視鏡器 種の選択としてはやはり1本にこだわらず，複数でそれ ぞれの器種の弱点をカバーするような組合せで行うべき であると考光ている.

最近は内視鏡による粘膜の拡大観察 ${ }^{7899) か ゙ ク ロ ー ス ゙ ア ~}$ ップされているが，この上うな観察法もゆくゆくは微小 胃癌の発見へと結びついてくるであろらが，現状ではま だそこまでは到達できず, 正常胃粘膜像の解析から萎縮 性変化，とくに腸上皮化生などの粘膜変化の所見の積み 重文を行っている段階である。

ともかく現在の内視鏡はまだ次々と改良がつづけら れ，1年もする之次の新しい器種が現われ，常に新しい ものを持ちつづけることさえ大変であるが，この辺で改 良ばかりではなく一段飛躍した発想も必要なのではない かとさえ思われてならないのである。

2）直視下胃生検の反省

生検技術は内視鏡器種によって多少異なることは当然 であるが，的確な狙撃とより良い生検材料の採取のため の基本的手技は常に变らないであろら.この胃生検の胃 癌に対する癌組織陽性成績を著明な施設からの報告でみ ると, 城島ら ${ }^{10)}$ は全胃癌で正諩率 $91.8 \%$, 早期胃癌で 90 $.8 \%$, 奥田 ${ }^{11}$ は早期胃癌で $95.8 \%$, 林ら ${ }^{12)}$ 早期胃癌で $95.7 \%$, 早川 ${ }^{13}{ }^{13}$ は早期胃癌生検での偽陰性率が $14.6 \%$ もあったと述べている。

消化器病センターに打ける最近の資料からこの点を検 討してみると，早期胃癌の生検正診率は $96.5 \%$ となる. 今これらを降起型（I，II a，I $\mathrm{a}+\mathbb{I} \mathrm{c}$ など）, 陥四型 ( II $\left.c, \mathbb{I} c+\mathbb{I} a, \mathbb{I}, \mathbb{I}+\mathbb{I} c, \mathbb{I} c+\mathbb{I}+と^{*}\right)$ に分け て，胃内のそれぞれの部位におけす正診率でみると，表 3のような結果となる. 全体として降起型の方が陌凹型 より成績が良く, 部位別には隆起型で胃体部の正診率が 悪く, 陷凹型では噴門, 次いで胃体部の成績が悪いこと 
表 3 早期罢癌の部位別生:検隄性:率

\begin{tabular}{|c|c|c|c|c|c|c|}
\hline \multicolumn{7}{|c|}{ （）忊は恼巣数 } \\
\hline & 幽鬥涧 & 倠 & 简体涑 & 噴鬥洲 & 小 & 計 \\
\hline 隆起型 & $100.0 \%$ & 100.0 & 92.0 & 100.0 & $97.9\left(\frac{94}{96}\right)$ & \multirow{2}{*}{$96.6\left(\frac{315}{326}\right)$} \\
\hline 陮叮型 & 96.4 & 96.7 & 95.7 & 93.3 & $96.1\left(\frac{221}{230}\right)$ & \\
\hline
\end{tabular}

表 4 隆起型早期胃嵒の大きさと部位別止診率

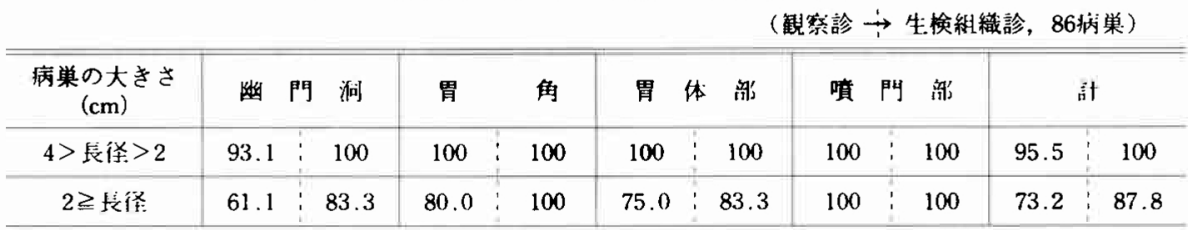

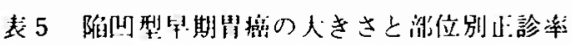

(觀察診 $\rightarrow$ 牛挨組織診, 205病巣)

\begin{tabular}{|c|c|c|c|c|c|c|c|c|c|c|}
\hline $\begin{array}{c}\text { 恼巣の大きさ } \\
(\mathrm{cm})\end{array}$ & 幽 & 时 翻 & 早 & 角 & 胃 & 部 & 噴 & 部 & \multicolumn{2}{|c|}{ 計 } \\
\hline $4>$ 長径 $>2$ & 77.3 & 95.5 & 80.3 & 98.4 & 82.4 & 98.0 & 83.3 & 100 & 80.7 & 97.9 \\
\hline $2 \geqq$ 長径 & 75.0 & 93.8 & 85.7 & 95.2 & 73.9 & 91.3 & 80.0 & 100 & 78.5 & 93.8 \\
\hline
\end{tabular}

が分る、これはまたファイバースコープでの直視下生検 の難易をむ良く反映した成績ではなかろらか.そこでさ らにこれらの成績を紐かく分析してみた。

隆起型早期胃癌の大きさ（病理肉眼所見での長径）之 部位とでの成績は表 4 の如くである．観察のみによる正 診率は大小を問わず幽門洞が意外に低率である.てして さらに生検結果をえての補正では $2 \mathrm{~cm}$ 以下の小さいも のでの正診率が胃体部においてあまり改善されないこと がよく分る。

また陌凹型早期胃癌でも表 5 のよらに隆起型で見たと 同様の傾向が現れているが，陥凹型ではさらに小さな病 巣で全般的に成績が低下することが示される.その上， 陥凹性病変でとくに胃体部後壁での生検結果がやはり最 も悪く,これは以前から度々指摘されている結果とよく 一致する.

以上のことを要約すると, 現在の胃ファイバースコー プでの早期胃癌の生検は胃内の部位では胃体部で最も成 績が悪く，ついで幽門洞といらことになり，陥凹型の早 期胃癌は病巣が小さくなればなる程, その正診率が低下 する傾向にあるといえよう．この点を改良ないしは注意 することはより多くの早期胃癌の発見にもつながるもの である。
ただこのような資料は多くの医師，それも教育中の人 達む含めた医師グループによって行われた生検結果であ り，かつまた多種類のファイバースコープが使用されて いることを念頭に置いていたたきたいものであるここく 最近の優れたファイパースコープー種で, しかるべテラ ンの内視鏡医のみが行えば，より優秀な結果が出るだる うと期待されるのであるが，これでも一般的な傾向を見 るためにはそれなりの意味があるように思う。

次に生検陰性であった陷凹型早期胃癌の 1 例を示して みよう.図2 は胃体下部大弯やや後壁例にある潰場性変 化の内視鏡写真であるが，部位的に見ても，辺縁の性状 からす悪性が疑われる.しかしこの辺縁からの生検 3 個 の組織像には覀性所見が認められなかった。切除標本の 組織検査の結果は未分化腺癌が証明された．ただこの腺 癌の範囲は潰瘍の辺縁にわずか $1 \mathrm{~mm}$ 程の幅で全周に存 在していたにすぎず, 生検組織片はついにこの部位から 採取されなかったことになる、つまり生検が確実にかつ たんねんに辺縁から採取されていれば，この症例は生検 陽性所見がえられたはずである。

3）噴門部早期胃癌の診断

胃上部ことに食道胃接合部から胃側 $2 \sim 3 \mathrm{~cm}$ までの範 囲の病変の診断は従来から大変むずかしいと考えられ 
図 2 胃体下部大弯の 丘型早期胃癌（生検偽陰性例）

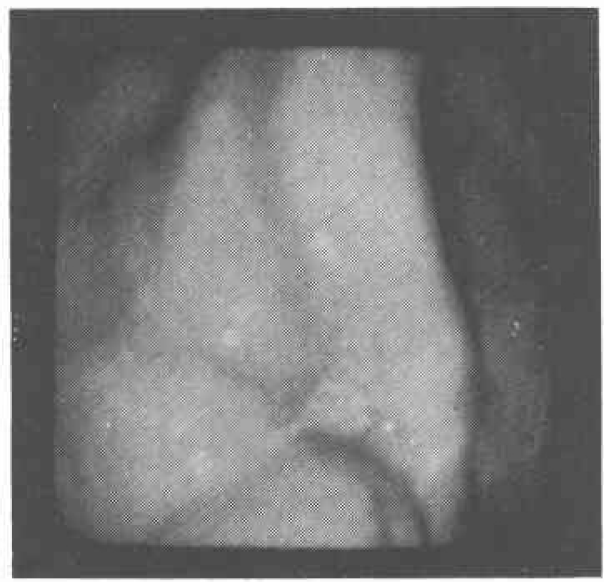

てきた。これは主として，この部位の観察なり撮影なり が機械的にも技術的にもむずかしかったことによる。そ してこれは胃カメラから始まるわが国に打ける内視鏡診 断学の普及発展から見れば当然のことか子知れないす なわち，長い期間にわたりわが国の胃内視鏡の主流が側 視式のスュープで占められてきたためのある種の弊害で あろう、側視式では噴門部は観察がむずかしいし，反転 操作は面倒だし，患者に苦痛を与えるといった感覚があ る.ところが現状の胃ファイバースコープは器種の項で も述べたように大変操縌性の優れたものが出迴っている ので噴門部の観察もかつてほど困難ではない。

あらろん多種類のスコープを持つことができるなら ば，この部位の観察にはなんといっても直視式のスコー プが良い．とくに接合部を全周に渡り観察するためには どうしても直視式でなくてはならないし，この部に病変 がある場合の側視式での Down 観察には大変無理があ る.

実際にこの部位の胃癌についてみると, まだまだ進行 癌が多く早期癌の占める割合は少ない。この意味でも部 位的な早期胃癌の診断で最も問題となるのはこの部位の 診断であろう.そこで著者らの資料から病巣の辺縁が接 合部より $2 \mathrm{~cm}$ 以内にあり術前に 診断された 長径が $2 \mathrm{~cm}$ 以下の早期癌を調べてみると，わずかに13病巣にすぎな いささらにこれらから接合部に接する長径 $1 \mathrm{~cm}$ 以下の 微小癌を探すと 3 例にすざず，わが国全体でのこれまで

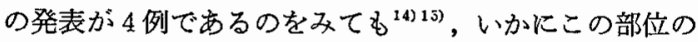
早期癌の発見頻度が少ないかがよく分るであるう。これ は決してこの部位の早期胃癌の出現率がこれほど低いか
図 3 食道胃接合部の微小 I a の内視鏡像

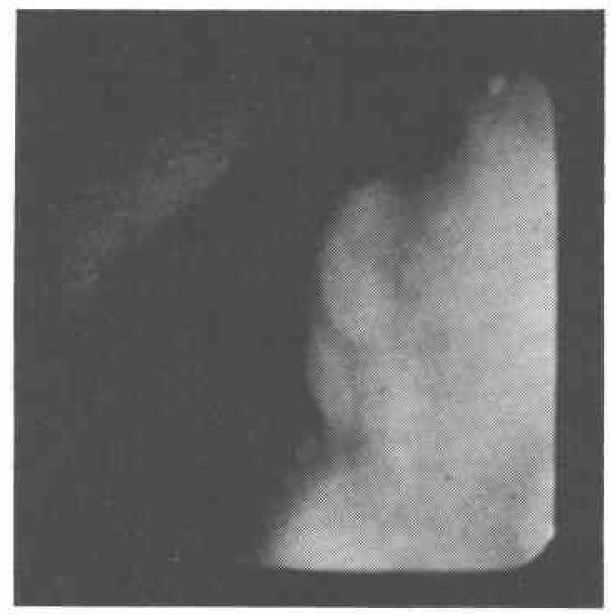

らであるとは思われない，そしてこれらの症例の発見経 過をみると, いずれの症例です直視式のファイバースコ ープで発見され，生検で癌陽性所見がえられている。

図 3 はこれらの症例の典型例を示すが，直視式の食道 ファイバースコープでの写真であり，食道胃接合部に小 隆起を観察することができる.この症例の切除標本での 大ささは $0.9 \times 0.5 \mathrm{~cm}$ であり，この部の微小癌として貴 重な症例である.な拊の 2 症例もいずれるII a 様の小 隆起として観察され, 標本でも明瞭に隆起として認めら れ,この部位の早期癌の発生と初期像を考える上に誠に 興味のある所見である.

4）II b 型および III 型の診断

確かに早期胃癌に対する内視鏡診断は飛躍的に進歩し てきた。しかしことII b や目型の診断となると依然とし て困難であると考えられている．とくにII b の診断につ いては何回か学会ですシンポシウムのテーマとして取り 上げられているが，ここ数年目立った進歩はないようで ある. III型についても同様なことがいわれているが，こ ちらはII b に比較して明らかに潰瘍性変华が存在するこ とによって診断はむしろ有利なはずである。それでもな 扐かつ典型的な II 型にはなかなか招目にかかれない.

著者らのII 症例からの診断経過を振り返ってみる と，II b の内視鏡診断はわずかな変化にも踌躇なく，丹 念に生検標本を採取すること以外には方法がないと結論 されるこのわずかな変化とは主として色調の変化（発 赤が多い)で,これに粘膜表面の微細模様の変化が加味 されたものがとくに要注意であり．このような変化をま ず探し出すことが基本であるが,これには色素法（とく 
にコントラスト法 ${ }^{17)-20)}$ ) が有用である。最近では昖大 能のきわめて優れたファイバースコープも市販されて拉 り,このような器種を用いての近接観察によって, 正常 の胃粘膜像と異なった所見をわすかかな範囲からも読み取 ることができれば，II b 診断も比較的に容易となるかる 知れない。

さらには後述するよらな色素染色法 ${ }^{21)-24)}$ ，峃光色素 法23)-34)，勝ら ${ }^{37)}$ が試みているような Remote Sensing の 応用，赤外線フィルムの活用などが今後さらに発展すれ ば五 $\mathrm{b}$ 診断のみならず，早期胃癌全体の発見頻度もすす ます向上することが期待される.

III型については，潰愓そのものの存在診断はむずかし くないはずであるから，やはり疑わしい症例での潰瑒縁 全周からの正確な生検が何にもまして重要であるといわ ねばならない。

5）微小胃癌

微小胃癌を切除生標本での病巣の長径が $1 \mathrm{~cm}$ 以内で 組織学的にもこれを越えて浸潤がない場合と定義する と，これに当てはまる早期胃癌は意外に少ない，最近で はこの制限をるら少し厳格にして, 長径は $0.5 \mathrm{~cm}$ 以内 とすべきだと主張する意見もある、ただここむで小さく してしまらと， $\mathrm{x}$ 線的にも内視鏡的にも全く偶然としか いいようのない発見のされ方のものや, 標本上で発見さ れたるのが増加するし，なんといっても全体の数がまだ まだごく少なくなってしまって, 病理学的には面白いか む知れないが，診断学の上で議論することがもずかしく なってしまう．現状ではまだ前者の定義に従って微小癌 を検討した方が賢明であるら。

著者らの施設での微小癌の病巣数は表 6 の上5に81病 单 (全早期胃癌の $11 \%$ ) であるが，この中で術前に診断 できたものは42病巣である.これをさらに細かく晾断経 過でみると， $\mathrm{x}$ 線で20病巣が見つかり，内視鏡で15病 巣, さらに生検で 3 症巣が発見されている.なお残りの 3 病巣は診断経過が明確ではなかった。

これら病巣の型別分類ではII a とII b が際立って多く なっているのが特徵的である. また小さい病巣であるだ けに著者らの锴小癌は単純な形態, つまり I， II a II b, II c の形を取るものが多く, 複合型が少なかったのは興 味深い所見である.さらにまた隆起型が幽門洞と噴門部 ことに食道胃接合部にごく近接した部位に多く見られる 傾向はこれらの病変の発生とも関連して,これまな大変 興味を引く現象であるう。

診断されたIIbの6病巣はいずれる発赤といった色調
表 6 微小胃癌症例

(70症例, 81 病巣)

\begin{tabular}{|c|c|c|}
\hline 型列 分 & 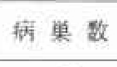 & 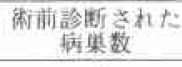 \\
\hline I & 5 & 2 \\
\hline II a & 27 & 16 \\
\hline $\mathrm{II} \mathrm{a}+\mathrm{IIc}$ & 2 & 2 \\
\hline II b & 23 & 6 \\
\hline II c & 20 & 14 \\
\hline$\Pi c+\Pi a$ & 1 & 1 \\
\hline III & 3 & 1 \\
\hline 竐 & 81 & 42 \\
\hline
\end{tabular}

変化として捕兄られ，生検によって確診されたものばか りであり，内視鏡観察時にはむしろ良性の変化とさ克考 えられたほどの病変で，もし的確な生㭘が行われてい なければ診断されていなかったかも知れない。これに反 し，陷四型 II $\mathrm{c}$ や隆起型 I ないし II a の中には内視鏡の 肉眼所見だけで，すでに癌であると確実に診断できたも のも多く,このようなものではたとえ小さいといっても 診断はそれ注ど困難ではない，要はいかにこの存在を発 見するかにある。

このように現在の診断学はたと光 $1 \mathrm{~cm}$ 以内の病変で あってもこの存在診断はそれほどむずかしいものではな くこれから確実な生検標本が採取されれば質的診断も 容易であるとい方る。微小癌の生検診断はだからといっ てやたらに生検標本を採取すればよいというすのですな い.普通,生検標本を 1 個採取すればそれに応じて出血が 起こる.この出血量によってはこれだけで $1 \mathrm{~cm}$ 直径程度 の範囲は覆いかくされてしまう。したがって微小病変の 生検には,できるだけ多くの標本を採取して,その中から 悪性変化を発見しょうなどという態度は許されない，と にかく，第 1 個目の生検をまず確実に行らことが肝腎て あろう．因みに微小癌からの生検標本採取順による癌陽 性組織出現率は表 7 のらになることが分っている ${ }^{16)}$.

\section{4. 新しい早期胃漹診断法の展開}

ここ数年来, 早期胃癌の診断にはとれはど目新しいる のは見当らないと最初にも記したが，内視鏡診断学全体 を見てみると，地味ではあるが多くの臨床医の努力の跡 をみることができる，それらのうち胃癌診断に利用され る代表的なるのを次挙げてみよう。

1) 色素内視鏡検査

胃癌の診断に限らず, 最近の内視鏡の分野で特筆され なければならないのがこの色素内視鏡検査法の発展であ 
表 7 溦小胃癌の生検順位別癌陽性率

\begin{tabular}{c|c|c|c}
\hline \hline 採取順位 & 生検個数 & 陽性個数 & 陽性率 (\%) \\
\hline 1 & 18 & 16 & 88.9 \\
2 & 18 & 11 & 61.1 \\
3 & 15 & 6 & 40.0 \\
4 & 11 & 4 & 28.6 \\
5 & 8 & 1 & 12.5 \\
6 & 4 & 0 & 0 \\
\hline
\end{tabular}

る.もともと色素を早期胃癌の診断に 導入したのは色 素撒布法としてであったが ${ }^{17) 18)}$ ，近年さらにこれが改 良されより効果的な方法が用いられるようになってき $た^{19)}{ }^{20)}$. さらにこの撒布法とは全く別に色素の持つ着色 ないしは染色効果を胃癌診断に用い上うとすることが試 みられ，色素着色法 ${ }^{21)-24)}$ とて登場してきた。そして また種々の色素の利用，その投与法の改良などさまざま な問題がクローズアップされ，現在これらを綜合的に統 一して，研究を便利にしようとする機運がある.

コントラスト沠（色素撒布法）では色素としてインジ ゴカルミン，エバンスブルーなどの非吸収性の色素が利 用される.最近ではブリリアントブルーが良いといら報 告 ${ }^{25)}$ むある.いずれにしてもこのコントラスト法も初期 のようにただ色素を撒布するだけではなく，蛋白分解醉 素による粘液の溶解, そしてさらにはこの色素によって 出現する胃小区像を近接観察するといったきめの細かい 方法む取られている. 井田ら ${ }^{26) 27}$ とよれば，これによっ て胃低腺，幽門腺域の区別のみならず早期胃癌の表面性 状も通常観察よりもはるかに区別し易いと述べられてい る.

色素着色法 (メチンンブルー染色法) む早期胃癌診断 の補助診断法として是非利用したい方法である．この染 色法はすでに胃粘膜腸上皮化生の診断 ${ }^{28)}{ }^{29}$ にはなくては ならない方法となっているが, 胃癌も高率に着色してく れる.しかし腸上皮化生の診断と胃癌の診断の場合とで はメチレンブルー色素の投与に違いがある.

表 8 亿色素の投与法を記載したが，このような投与法 を行うのは腸上皮化生の着色が比較的早い時間内（1 2 分）に起こり, しかも消失も早いのに反し, 胃癌の着 色には長時間（30分以上）が必要であるし，一旦着色す るとその消失にも時間がかかるからである. 図4にこの 手法による II c の典型的な着色像を示しておく．またこ の方法が行われた症例での着色率は表 9 にあげてるよ らに大変高率である。この率は着色をどの程度までとる かによって随分変ってくるものであるが，病変の一部に
表 8 ×チレンブルー染色法

1。撒 布 法

$0.1 \sim 0.5 \%$ ×チレンブルー液を值視下゙に

胃粘膜上:に撒布

2 - 3 分後, 水で洗滌

2. 以服法

$150 \mathrm{mg}$ メチレンプルー1カプセルを

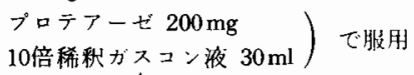

$\downarrow$ 体位変換

$2.5 \sim 3$ 時間後内視鏡検植.

表 9 メチレンブル一染色法による胃癌の着色率

\begin{tabular}{c|c|c|c|c}
\hline \hline 進 行度 & 病巣数 & 着色数 & 非着色数 & $\begin{array}{c}\text { 着色率 } \\
(\%)\end{array}$ \\
\hline 進行胃溒 & 37 & 34 & 3 & 91.9 \\
芰期胃癌 & 116 & 103 & 13 & 88.8 \\
\hline it & 153 & 137 & 16 & 89.5 \\
\hline
\end{tabular}

着色をみたものや，程度のごく薄いるのる含めてある。 このような見方をしても，約10\%前後に非着色例をみる ことは事実で，このような症例での組織所見はすべて癌 組織が非癌性の上皮で被われているるのであった。した がってスキルスのような癌巣では本法も当然無効という ことになる。この事は本法を応用する場合に十分注意し なければならない重要な点である。

いずれにしても，メチレンブルー染色法によって，わ ずか $5 \mathrm{~mm}$ ほどの微小癌も猃断されているという事実 は，今後の早期癌診断に大変明るい資料を与兄ているよ らに思う。

2）蛍光色素法

これも后い意味の色素内視鏡検查に入るものである が，手技や機序がいくぶん異なるので，ここでは別に扱 5. 蛍光色素を用いた内視鏡検査の歷史もそれ汪ど新し いものではない，胃カメラの全盛期にすでに吉利 ${ }^{30)}$ ，大

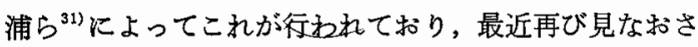
れてきている.勝ら ${ }^{32) 33}$ はフルオレスチン静注によって この方法の再評価を行い興味ある成績を報告している. また加藤ら ${ }^{34)}$ はアクリジン・オレンジの経口投与によっ て良い成績をえている.

フルオレスチン静注法では蛍光発現の時間差が大变重 要な意味を持つものであるが，この発現時間が非常に 早いことにこの検査の難があるといわれている.アリリ シン・オレンジの経口法ではメチレンブルー染色法と同 様に直接癌組織の露出していないような組織形態を示す 
因 4メチレンブルー染色法によるII

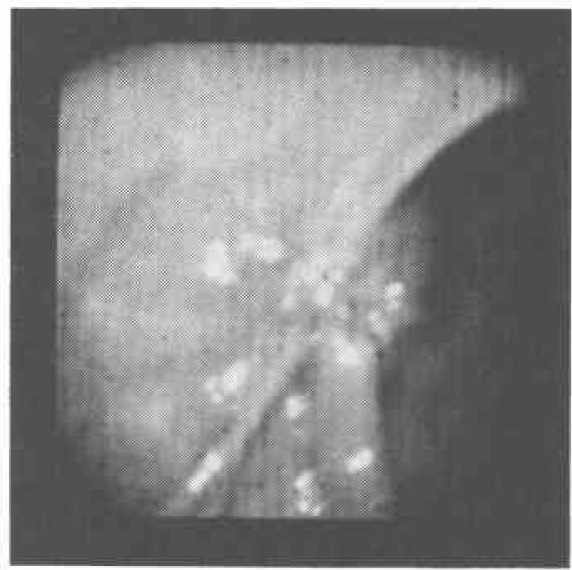

通常内視鏡像

ものではやはり蛍光の発現が悪いといら弱点がある．現 状ではどちらの方法が優れているかといった䦗題ではな く，まだをた゚この方法は未熟であり，今までの研究を基 盤にしてさらに一層の発展改良が必要で西ろう。

3）その他の方法

胃癌をより発見し易くしようとする方法は今まで確実 なるのがないだけに色々な試みがある。ここではそれら のらちで代表的なものを挙げてみよう.

従来から使用されているコンゴーレッド色素る胃底腺 領域内の診断に役立つといら竜田ら ${ }^{35)}$ の研究がある.

鎌田ら ${ }^{36)}$ はアズールA色素を用いて粘液染色を行い， 粘液と病変との相関を細かく検討しているが，Mucosal barrier の 1 つとしての粘液性状・分布を分析して癌猃 断とも関連した大変興味ある成果を上げている.

また最近では，資源開発の面で注目をあびている Remote sensing を内視鏡診断に応用しようする試み ${ }^{37)}$ あある。まだまだ実用段階には至っていないが，消化管 内視鏡竝断の将来を暗示しているかのような夢をいだか せるものである.こういった面での研究は臨床医学者の みの力では到底無理なるのであって，大きな機関，施設 との協力が是非必要である.

\section{5. 胃癌発生母地の問題}

最近のメチレンブルー染色法の発展, 実験胃癌の詳細 な追求は従来からしばしば大きな関心を抱かせていた胃 癌の発生母地とは何か, といら問題をにわかにクローズ アップさせてきた。 これは早期胃癌，とりわけ微小癌の 診断を追求して行くと必ずや直面する問題でああるわけ で，まさに早期胃癌研究の究極でもあろう.だからとい

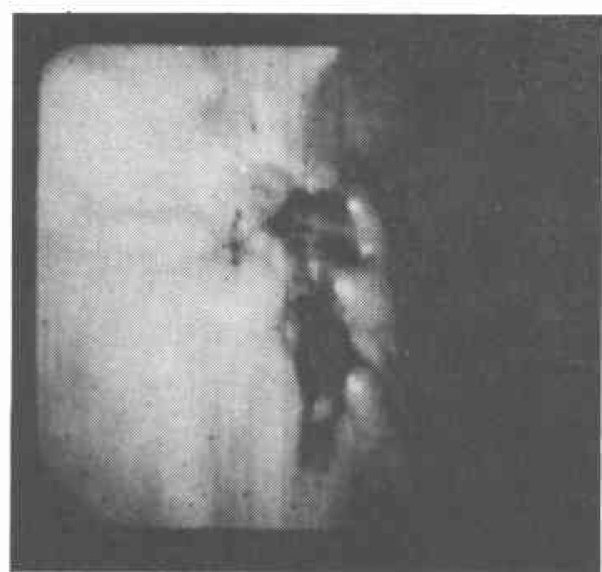

着色像

ってこの問題がそう簡単に解決するはずはない。

メチレンブルー染色法は腸上皮化生の診断をきわめて 容易なものとした。そこで今までは病理組織学的にしか 研究されていなかった胃病変と腸上皮化生との関連も生 体内で容易に研究できるようになった．表10は主病変と 内視鏡的に染色される腸上皮化生との合併頻度を示した ものであるが，従来からいわれている病理組織学的な合 併頻度とほぼ同様な傾向であり，やはり胃癌に合併する 頻度が最も高くなっている。

次に胃癌の組織型と染色腸上皮化生は表11の上らな相 関を示し，高分化型腺癌の腸上皮化生合併率 は $100 \%$ と

表10 胃聅患と晹上皮化生の合併頻度

\begin{tabular}{|c|c|c|c|c|}
\hline \multirow{2}{*}{ 聅 } & \multirow{2}{*}{ 怔例数 } & \multicolumn{2}{|c|}{ 脂上.佊化生の有無 } & \multirow{2}{*}{$\begin{array}{c}\text { 合併率 } \\
(\%)\end{array}$} \\
\hline & & 有 & 無 & \\
\hline 旨拈 & 65 & 53 & 12 & 81.5 \\
\hline 胃ポリーブ & 17 & 8 & 9 & 47.1 \\
\hline 青十二指晹潰瘍 & 36 & 22 & 14 & 61.1 \\
\hline 慢悱: 狊 炎 & 54 & 36 & 18 & 66.7 \\
\hline s̀t & 172 & 119 & 53 & 69.2 \\
\hline
\end{tabular}

表11 胃癌の組織型と腸上皮化生の合併頻度

\begin{tabular}{|c|c|c|c|c|}
\hline \multirow{2}{*}{ 組 織 型 } & \multirow{2}{*}{ 病巣数 } & \multicolumn{2}{|c|}{ 腸上:皮化牛:の有無 } & \multirow{2}{*}{$\begin{array}{c}\text { 合併率 } \\
(\%)\end{array}$} \\
\hline & & 有 & 無 & \\
\hline \multirow{3}{*}{ 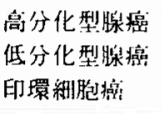 } & 40 & 40 & 0 & 100.0 \\
\hline & 22 & 14 & 8 & 66.6 \\
\hline & 13 & 7 & 6 & 53.8 \\
\hline 計 & 75 & 61 & 14 & 81.3 \\
\hline
\end{tabular}


なる.このことは胃癌の中でむ高分化型の腺癌は腸上皮 化生と大変密接な関係を有することを暗示している。し かしこのことから直ちに腸上皮化生から分化型癌が発生 すると結論することはできないが，このような变化をむ たらす胃粘膜の状態が癌発生と深い関係にあることは想 像に難くない。

一方, 染色腸上皮化生を内視鏡的汇観察すると，それ らは隆起型, 平坦型そして宿句型の基本 3 型に大別でき る.これらの胃内に批りる分布は隆起型は幽門洞に，陷 叮型は胃体部に，そして平坦型はこれらの中間的な領域 に存在することが多い。このようなことから著者らは腸 上皮化生の発生経過の一部に陌凹型 $\rightarrow$ 平坦型 $\rightarrow$ 隆起型と なる発育過程を推測している.そして高分化型腺癌の周 囲に存在する腸上皮化生にはこの隆起型の併存する頻度 が高いことが分ってきた。

以上のような腸上皮化生の経過や発癌の様子を人胃で 観察することは大変むずかしいことで，この実証は誠に 困難である.幸いなことに最近は実験胃癌の経過観察が 綿密に行われ，この発癌以前に腸上皮化生がみられたと いう報告 ${ }^{38)}$, さらには胃粘膜への放射線照射中に化生上 皮の出現をみたといら報告 ${ }^{39)}$ みられるよらになった。 そこで著者らはNG 投与犬に定期的に内視鏡検査をメチ レンプルーを用いながら行い腸上皮化生の出現, 染色状 態を検討中である ${ }^{40) 41)}$. 近い将来, この問題む必ずや解 決できるものと期待している.

\section{おわりに}

早期胃癌竞断の現状を反省をむ含めて多方面から記し てきたが，どれる決して飛躍的であったり，画期的であ ったりしたすのはここ数年間にはみられなかった。しか し地味ではあるが着実な進歩が少しづつ進んでいること は事実である.内視鏡器種1つを取りあげてもそうであ るし，検查手技にしてるそうである，恐らく将来この両 面でさらに飛躍的な発展がみられるであろう。るもあれ 現状でも早期胃癌の遠隔成績は誠にすばらしいものであ ることを再認識し, 胃癌を 1 例です多く早期癌の状態で 発見し治療することが，現在の癌治療の中でもまだまだ 重要であることを強調したい。

\section{文献}

1）栗田英男：過渡期に立つ胃集検活動の課題，厚 生の指標, $25(5), 29-32,1978$.

2) 林田健男注：早期胃癌の遠隔成績。胃と腸, 4, 1077-1085, 1969.

3) 北岡久三注か：早期胃癌の手術成績, 外科, 36, 1468-1469, 1974.
4) 本田利男: 早期胃癌十年遠隔成績一40施設の集 計報告一, Gastroent. Endoscopy 19, 613-629， 1977.

5)遠藤光夫ほか：癌手術の遠隔成績, 食道, 外科 診療, 18, 863-867, 1976.

6) 遠藤光夫 : 最近の胸部食道癌診療上の問題点. 日本胸部臨床，36，887-892，1977.

7) 丸山正隆注か：拡大胃内視鏡 Magnifying Fibergastroscope (FGS-ML) type 2 の使用経験. Gastroent. Endoscopy, 13, 358-363, 1971.

8) 大石雅巳注か：胃粘膜微細病变の拡大観察, Gatroent. Endoscopy, 20，189-191，1978.

9)榊 信広浪：胃炎粘膜の拡大観察と病態生 理, Gastroent. Endoscopy, 20, 191-193, 1978.

10）城島嘉昭ほか：胃生検の実態と反省, Gastroent. Endoscopy，14，206-208，1972.

11) 奥田 茂：胃生検の反省と今後の問題, Gastroent. Endoscopy, 14, 221-224, 1972.

12) 林学ほか：胃生検の評価と反省一鑑別診断 を中心としてー. Gastroent. Endoscopy, 14, 208-209, 1972.

13）早川尚男ほか：胃生検の評価と反省一偽陰性例 を中心に一. Gastroent. Endoscopy, 14, 209211,1972 .

14）鈴木 茂ほか：食道・噴門境界部の微小癌. 胃 と晹， $11 ， 697-704,1976$.

15)村上平注か：食道・胃接合部微小胃癌の内視 鏡診断之病理. Gastroent. Endoscopy, 20, 623$629,1978$.

16)鈴木 茂ほか：微小胃癌の生㭘. 胃之腸, 5, 971-976, 1970 .

17）津田靖彦ほか：特殊な方法による胃微細病变の 観察. Gastroent. Endoscopy. 9, 48, 1967.

18）青木誠孝ほか：慢性胃炎の内視鏡診断殊に色素 剤撤布法の立場から. Gastroent. Endoscopy, 10, 141-142, 1968 .

19) 并田和德ほか：胃内視検查における色素撤布法 の応用一第 1 報 基礎的検討一. Gastroent. Endoscopy, 14, 261-266, 1972.

20) 井田和德ほか：色素撤布法に関する工夫とそれ による胃粘膜表面所見の榆討. Gastroent. Endoscopy 14, 340-341, 1972 .

21）鈴木 茂活か:選択的胃粘膜染色法の内視鏡的 険討. Gastroent. Endoscopy, 14, 502- 503, 1972 .

22）鈴木 茂ほか：早期胃癌の内視鏡的着色法. 胃 と腸, 8,87, 1973.

23）鈴木 茂注か：胃内視鏡的色素着色法の研究。 Gastroent. Endoscopy, 15, 681-688，1973.

24）鈴木茂ほか：色素内視鏡検查による胃癌の診 断. 消化器内視鏡検査のトピックス, p. 123131, 医学図書出版, 1978.

25）依光幸夫ほか：胃疾患における色素内視鏡法の 檢討, 特にブリリアント・ブルー法を中心に, 消 
化管の癌に対する色素内視鏡検査，p. 33-40， 医学図書出版, 1978.

26）井田和德ほか：胃内視鏡検査における色素撤布 法の応用一第 2 報. 胃底腺および幽門腺領域の 識別とそれそれの粘膜所見. Gastroent. Endoscopy, 15, 37-40, 1973.

27) 井田和德泀か：色素内視鏡検査による胃癌漫潤 範囲の䛦断。胃之腸，12，1043-1054，1977。

28）井田和德注か：胃内視鏡検查における色素撤布 法の応用. 第 6 報, 胃粘膜ことに腸上皮化生の 生体染色. Gastroent. Endoscopy, 15, 671-678, 1973.

29)鈴木 茂注：腸上皮化生をめぐる諸問題（II） 腸上皮化生の内視鏡診断. 東女医大誌， 45, 565-572, 1975.

30) 吉利和ほか：胃粘膜営光撮影について. Gastroent. Endoscopy， 6，209，1964.

31）大浦辰男ほか：悪性董瘍組織親和性物質の臨床 的応用に関する基脴的研究. Gastroent. Endoscopy, 6, 210, 1964 .

32) 勝 健一ほか: 蛍光胃内視鏡の臨床応用の試 み. Gastroent. Endoscopy, 27, 391-399, 1975.

33) 勝健一ほか：蛍光色素剂を用いた内視鏡検査 法, 色素内視鏡検査の手技と応用, 99-106, 医 学図書出版, 1977.

34) 加藤 晃: Acridine Orange 営光色素を利用し
た胃の内視鏡検查法. Gastroent. Endoscopy, 12, $351-360,1970$.

35）竜田正晴ほか：Congo red 色素を用いた胃の内 視鏡的機能検査法一胃癌の早期診断への応用 一, 消化管の癌に対する色素内視鏡検查, p. 121-130, 医学図書出版, 1978 .

36) 鎌田武信ほか：In vivo 染色による胃 mucous barrier の内視鏡に上る検討, 胃癌表層粘液層の 偏倚, 消化管の癌に対する色素内視鏡検査, p. 41-46, 医学図書出版, 1978.

37) 勝健一汪か：遠隔探知方式 (remote sensing) の内視鏡的応用. Gastroent. Endoscopy. 20, 303, 1978.

38) Sugimura, T. et al.: Tumor production in the glandular stomach and alimentary tract of the rat by $\mathrm{N}$-methyl-N-nitro-N-nitrosoquanidine. Cancer Res., 30: 455-465, 1970.

39）渡辺敦光ほか：Wister ラットに X 線照射によ

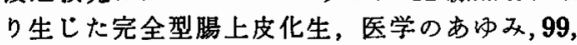
135-137, 1976.

40)鈴木 茂ほか: 実験胃癌犬における腸上皮化生 の発生とその診断. 胃と腸，12，1072，1977.

41）橋本忠美ほか：実験胃窝犬における腸上皮化生 の色素着色法による診断。消化管の癌に対する 色素内視鏡検査, 73-78, 医学図書出版, 1978 . 